九州大学学術情報リポジトリ

Kyushu University Institutional Repository

\title{
Micronutrients' Foliar Fertilization and Releasing Green Lacewing Chrysoperla Carnea (Stephens) Could Efficiently Suppress Sugar Beet Insect Pests
}

YOUSSEF, Asmhan E.

Economic Entomology Department, Faculty of Agriculture, Kafrelsheikh University

IBRAHIM, Amira S.

Economic Entomology Department, Faculty of Agriculture, Kafrelsheikh University

BAZAZ0, Kamal G.

Plant Protection Research Department, Sugar Crops Research Institute, Agricultural Research Center

KHATTAB, Hend M.

Economic Entomology Department, Faculty of Agriculture, Kafrelsheikh University

他

https://doi.org/10.5109/4103890

出版情報: 九州大学大学院農学研究院紀要. 65 (2)，pp.269-275，2020-09. Faculty of Agriculture， Kyushu University

バージョン :

権利関係 : 


\title{
Micronutrients' Foliar Fertilization and Releasing Green Lacewing Chrysoperla Carnea (Stephens) Could Efficiently Suppress Sugar Beet Insect Pests
}

\author{
Asmhan E. YOUSSEF ${ }^{1}$, Amira S. IBRAHIM ${ }^{1}$, Kamal G. BAZAZO ${ }^{2}$, Hend M. KHATTAB ${ }^{1}$, \\ Takatoshi UENO ${ }^{3 *}$ and Kareem M. MOUSA ${ }^{1,3}$
}

\author{
Laboratory of Insect Natural Enemies, Division of Biological Control, Department of Applied Genetics and Pest Management, \\ Faculty of Agriculture, Kyushu University, Fukuoka 819-0395, Japan \\ (Received May 22, 2020 and accepted May 27, 2020)
}

\begin{abstract}
Sugar beet is attacked by many mischievous insect pests. To avoid too much reliance on pesticides, many studies have been conducted to search alternative methods of sugar beet pest control. In the present study, we evaluated whether pant fertilization and biological control could be efficacious techniques to suppress insect pests of sugar beet. In two successive growing seasons of 2015-2016 and 2016-2017, we investigated the impacts of Nutrimix ${ }^{\circledR}$ complete, a foliar fertilizer with concentrated micronutrients including nitrogen and sulfur, and also release of the common green lacewing Chrysoperla carnea larvae, a generalist predator of insect herbivores, on insect pest infestation in the sugar beet fields. Applications of the foliar fertilizer significantly decreased the percentages of plants infested by cotton leaf worms or sugar beet beetles, while the infestations by sugar beet flies and the sugar beet moths were less influenced. Releasing the predator $C$. carnea in sugar beet fields was found to effectively reduce pest populations though the effectiveness depended on the seasons. The plants in lacewing-released plots were attacked by fewer aphids, sugar beet moths, leafhoppers and sugar beet flies than those in control plots. Aphid populations were the most influenced, and the reduction percentages reached 100\% in the 2015-2016 season and 97.08\% in 2016-2017 after 14 days of release, while the sugar beet flies were the least influenced with $64.84 \%$ and $49.88 \%$ reduction in the first and second seasons, respectively. Our study demonstrated the usefulness of micronutrient application and $C$. carnea larvae for suppressing insect pest populations in sugar beet fields.
\end{abstract}

Key words: foliar fertilization, insect pest populations, insect predators, plant nutrition, common green lacewing, natural enemies

\section{INTRODUCTION}

Sugar beet, Beta vulgaris L., is grown for sugar production and occupies around twenty percent of sugar production in the world (FAO, 2009). In addition, sugar beet has recently been received much attention for its high potential to produce biofuel or ethanol (Maung and Gustafson, 2011). It is also an important crop in Egypt, playing a vital role in the crop rotation system in the Egyptian fields, and the cultivated area in 2017 was 236,732 hectare with total production reached 12,106,661 tons (Anonymous, 2019). The Egyptian government has been encouraging growers to increase sugar beet production because a gap between sugar production and consumption is large.

Numerous insect pests attack sugar beet throughout growth stages and harm directly and indirectly the taproot (Evaristo, 1983), often causing a great yield loss and quality decrease (Bassyouny, 1993). Under Egyptian ecosystems, the main insect pests of sugar beet are: cotton leafworm Spodoptera littoralis (Boisd.) and S. exigua Hübner, sugar beet fly Pegomya mixta Vill., sugar beet beetle Cassida vittata Vill., and sugar beet

\footnotetext{
Economic Entomology Department, Faculty of Agriculture, Kafrelsheikh University, Kafr El-Sheikh 33-516, Egypt

2 Plant Protection Research Department, Sugar Crops Research Institute, Agricultural Research Center, Egypt

Institute of Biological Control, Faculty of Agriculture, Kyushu University, Fukuoka 812-8581, Japan

* Corresponding author (E-mail: ueno@grt.kyushu-u.ac.jp)
}

moth Scrobipalpa ocellatella Boyd.; these pests are commonly abundant in sugar beet plantations in Egypt throughout plant growth stages (Metwally et al., 1987; Abo-Aiana, 1991; Amin et al., 2008; Badawy and Shalaby, 2015). Although farmers rely strongly on synthesized chemical pesticides, growing attention has been paid to avoid overuse or misuse of pesticides. Then, insect pest control in sugar beet should be based on integrated pest management (IPM) programs, in which pesticides may be carefully used to avoid pernicious impacts on natural enemies, development of pesticide resistance, and environmental hazardousness (Ueno, 2006; Ueno and Tran, 2015). In this context, applying combinations of other practices, such as use of inter-cropping technique, plant extracts, resistant varieties, natural materials, is advantageous to minimize insect pest overrun and to the sustainable use of biodiversity (Gu et al., 2008; Scherr and McNeely, 2008; Ebadollahi and Mahboubi, 2011; Mousa et al., 2013; Badawy and Shalaby, 2015; Elsharkawy and Mousa, 2015; Mousa and Ueno, 2019).

Here, we first focus on a foliar fertilizer to evaluate whether it could be incorporated into IPM programs in sugar beet fields. Agricultural crops require macronutrients and micronutrients to grow normally, and the deficiency of such nutrients causes stunted growth and decreased plant resistance to insect herbivores and plant disease (Reddy, 2017). Fertilizers are, hence, applied commonly to improve the nutritional status of the crops by optimizing or maximizing crop growth. Crop growth is associated with nutritional or physiological state of the 
crops, which can affect pest severity. In fact, use of nitrogen fertilizers is known to increase pest severity whereas phosphate or potassium fertilizers may rather decrease pest damage (Lu et al., 2007; Reddy, 2017). Also, pest damage may depend on type of fertilizers (Rakshit, 2013). We therefore expect selection of appropriate fertilizers may help reduce pest damage in sugar beet fields.

Second, we focus on the usefulness of biological control in sugar beet fields. Biological control, i.e., use of natural enemies, has long been recognized as an effective method in regulating insect pest populations (Wang et al., 2001; Bassiony et al., 2017; Perez-Alvarez et al., 2019) and are useful for sustainable crop production (Bale et al., 2008). The common green lacewing Chrysoperla carnea (Stephens) is a common and widespread polyphagous predator belonging to the family Chrysopidae (Brooks, 1994; Wang and Nordlund, 1994; Tauber et al., 2000). Although the adults feed on nectar and pollen (Villenave et al., 2005), the larvae are active predators, preferentially feeding on aphids (Tauber et al., 2000), whitefly (Alghamdi et al., 2018), thrips (Khan and Mores, 1999), leafhoppers (Daane et al., 1996) and even soft-bodied caterpillars (Lopez et al., 1976). This predator is commercially available as a bio-control agent against multi pest species (Tauber et al., 2000).

No previous studies have examined whether Chrysoperla carnea could be effective in controlling sugar beet insect pests though the larvae of this green lacewing had been frequently used in augmentative biocontrol programs (Hagley and Miles, 1987; Wang and Nordlund, 1994; Turquet et al., 2009). However, this predator is one of the major natural enemies widely found in agricultural fields of Egypt, and is also commonly observed on sugar beet plants. We thus expect that $C$. carnea can be incorporated for IPM programs in sugar beet fields.

Accordingly, the present study was carried out to examine the efficacies of foliar fertilization and $C$. carnea in suppressing the four main sugar beet insect pests. Field studies were therefore designed, and foliar spray of micronutrients and release of green lacewing larvae were made in sugar beet fields. Based on the results, we discuss usefulness of foliar fertilizers and biocontrol agents in sugar beet IPM.

\section{MATERIALS AND METHODS}

\section{Micronutrient fertilization}

Experimental setup

This experiment was carried out in the two successive growing seasons in 2015-2016 and 2016-2017 at the experimental farm of Sugar Crops Research Institute, Sakha, Kafer El-Sheikh, Egypt. An area of $700 \mathrm{~m}^{2}$ was measured and wasdivided into two parts, each with three sampling plots. Then, the area was planted with the sugar beet variety Farida as multigerm seeds in midSeptember. The area was uniformly fertilized with the recommended values of $\mathrm{N}-\mathrm{P}-\mathrm{K}$, and no pest control practices, including insecticide applications, were made throughout the growing seasons (except the following experimental treatments).

\section{Chemicals used}

To study the influence of foliar fertilization with micro elements on the major sugar beet insect pests, Nutrimix ® complete (Table 1), obtained from Shoura Chemicals Co., Egypt, was sprayed (720 gm/ha) using a manual hand sprayer during the last third of October in both seasons. Experimental plots were treated with Nutrimix while the others for the control were sprayed with water.

Table 1. The chemical composition of the synthesis Nutrimix ${ }^{\circledR}$ complete

\begin{tabular}{cc}
\hline Element & Concentration (\%) \\
\hline Zinc & 3 \\
Iron & 3 \\
Manganese & 4 \\
Magnesium & 1.8 \\
Copper & 3 \\
Molybdenum & 0.04 \\
Sulfur & 15 \\
Nitrogen & 3.5 \\
EDTA & 57 \\
\hline
\end{tabular}

\section{Data collection}

Five days after application, ten plants from each plot were randomly examined to record damaged plants that were infested by the main insect pests, i.e. cotton leaf worm (= beet armyworm) Spodoptera exigua HÜbner, sugar beet fly Pegomya mixta Vill., sugar beet beetle (= tortoise beetle) Cassida vittata Vill., and sugar beet moth Scrobipalpa ocellatella Boyd. This sampling procedure was repeated on the weekly basis until harvest. Sugar beet taproot weight (ton/hectare) and sugar content (\%) were calculated at the end of the experiment. The percentage of sugar in taproot was estimated with the aid of a refractometer.

\section{Green lacewing releasing}

Experiment setup

In order to examine the efficiency of the green lacewing Chrysoperla carnea, a field study was carried out in two successive seasons of 2015-2016 and 2016-2017 at two locations. The first location was at Sugar Crops Research Institute, Sakha Agricultural Research Station; this location was used for the releasing of the predator. Another location was at the experimental farm of the Faculty of Agriculture, Kafrelsheikh University and was used as a control area. Both fields were located in the same region with seven $\mathrm{km}$ apart from each other. The two study fields were similar in terms of soil structure and the atmospheric conditions. In this study, the variety Halawa was planted in mid-October, and both fields had an area of $700 \mathrm{~m}^{2}$. In each study field, pest insects were sampled from four plots. No insecticides were applied during the study period. 


\section{C. carnea}

Larvae of $C$. carnea were obtained from the Green Lacewing Mass Rearing Center, Faculty of Agriculture, Cairo University. In the last week of March, 2800 lacewing larvae in all (a mixture of first, second and third instars) were released in the first field by placing them on the plants using a fine brush.

\section{Data collection}

The first sampling was done before the release of the predator. Ten plants from each plot were randomly chosen and inspected directly in the field to count pest insects. Forty plants in all were thus sampled from each study field. Because the green lacewing requires 3 days to develop between $1^{\text {st }}, 2^{\text {nd }}$ and $3^{\text {rd }}$ instars, subsequent sampling were made after 3, 7, 10 and 14 days after releasing. The numbers of aphid (nymphal and adult stages), C. vittata (larval stage), S. ocellatella (larval stage), leaf hoppers (nymphal and adult stages) and $P$. mixta (larval stage) were recorded.

The reduction percentage was calculated according to Henderson and Tilton's equation (1955) as follows:

$$
\text { Population reduction } \%=100 \times\left(1-\frac{\mathrm{Ta} \times \mathrm{Cb}}{\mathrm{Tb} \times \mathrm{Ca}}\right)
$$

where: $\mathrm{Ta}=$ population density in a treated plot after treatment, $\mathrm{Tb}=$ population density in a treated plot before treatment, $\mathrm{Ca}=$ population in control after treat- ment, and $\mathrm{Cb}=$ population density in control before treatment.

\section{Statistical analyses}

The collected data were statistically analyzed using COSTAT software version 6.4. Analyses of variance (ANOVA) were applied to examine significant differences in means, and, then, the means were compared using Tukey's HSD test at a significance level of 0.05.

\section{RESULTS AND DISCUSSION}

\section{Micronutrients fertilization}

In the current study, we examined the impact of a foliar fertilizer, Nutrimix ${ }^{\circledR}$ complete, on the infestation percentages of four main sugar beet pests, i.e., S. exigua, P. mixta, C. vittata and $S$. ocellatella, during the two growing seasons in 2015-2016 and 2016-2017. In the first season, after five days of foliar application with the synthesis micronutrients, the percentages of sugar beet plants infested by $S$. exigua and $C$. vittata were significantly lower in treated plots than in control plots, in the first season of 2015/2016 $(F=13.5 ; P=0.021$ for $S$. exigua and $F=36.57 ; \mathrm{P}=0.0038$ for $C$. vittata), respectively (Fig. 1). Similar trends were detected for $P$. mixta and $S$. ocellatella though the differences were not significant or marginal $(F=4.5, P=0.101$ for $P$. mixta; $F=7.69 ; P=0.050$ for $S$. ocellatella) (Fig. 1 ). It appeared that that the foliar fertilizer most negatively
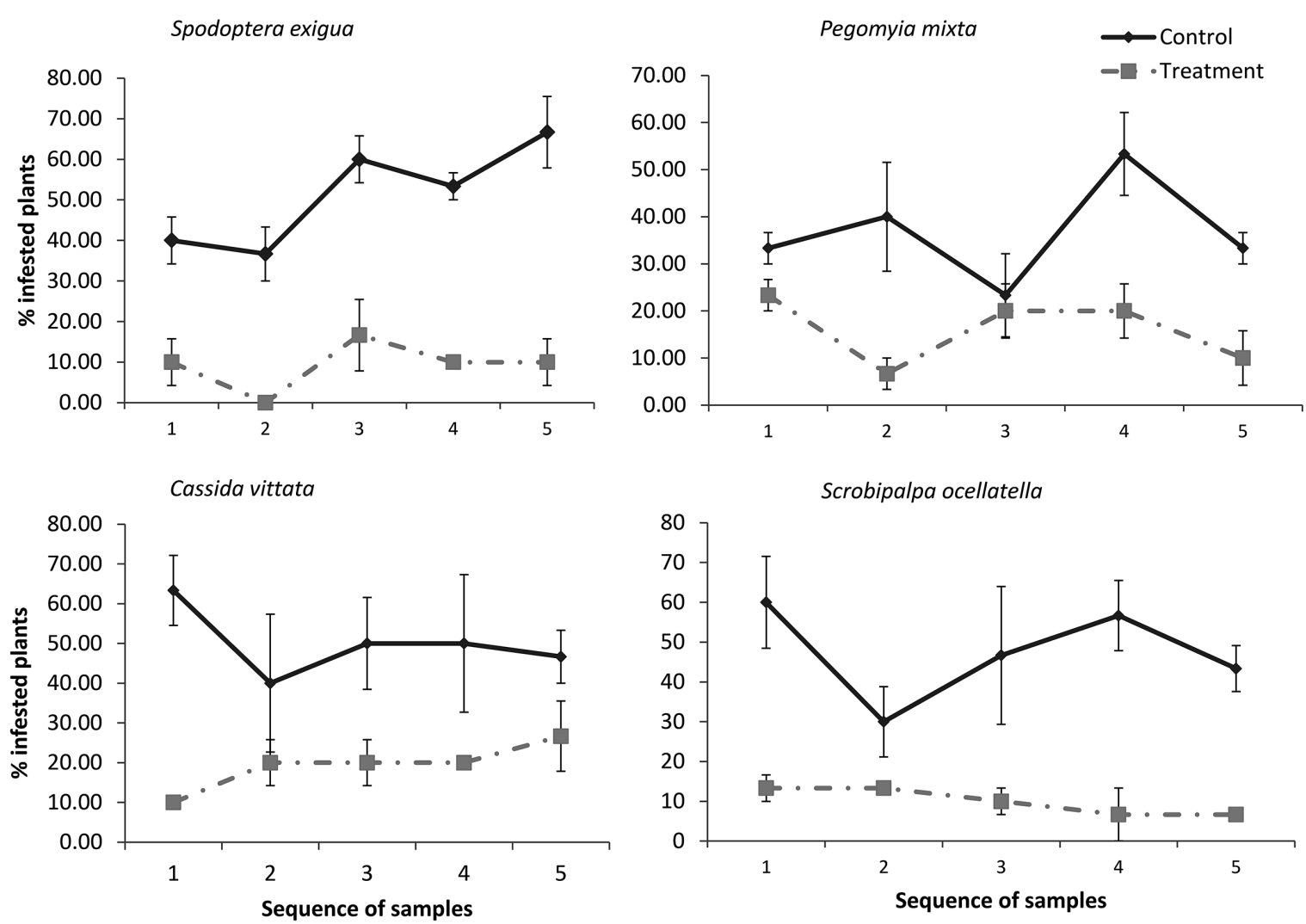

Fig. 1. Mean percentages of infested sugar beet plants treated with Nutrimix® complete or with water (control) in the first season 2015-2016. Sampling was made weekly from 5 days after the fertilizer treatment (from end of October till mid-November). Vertical lines indicate standard errors. 

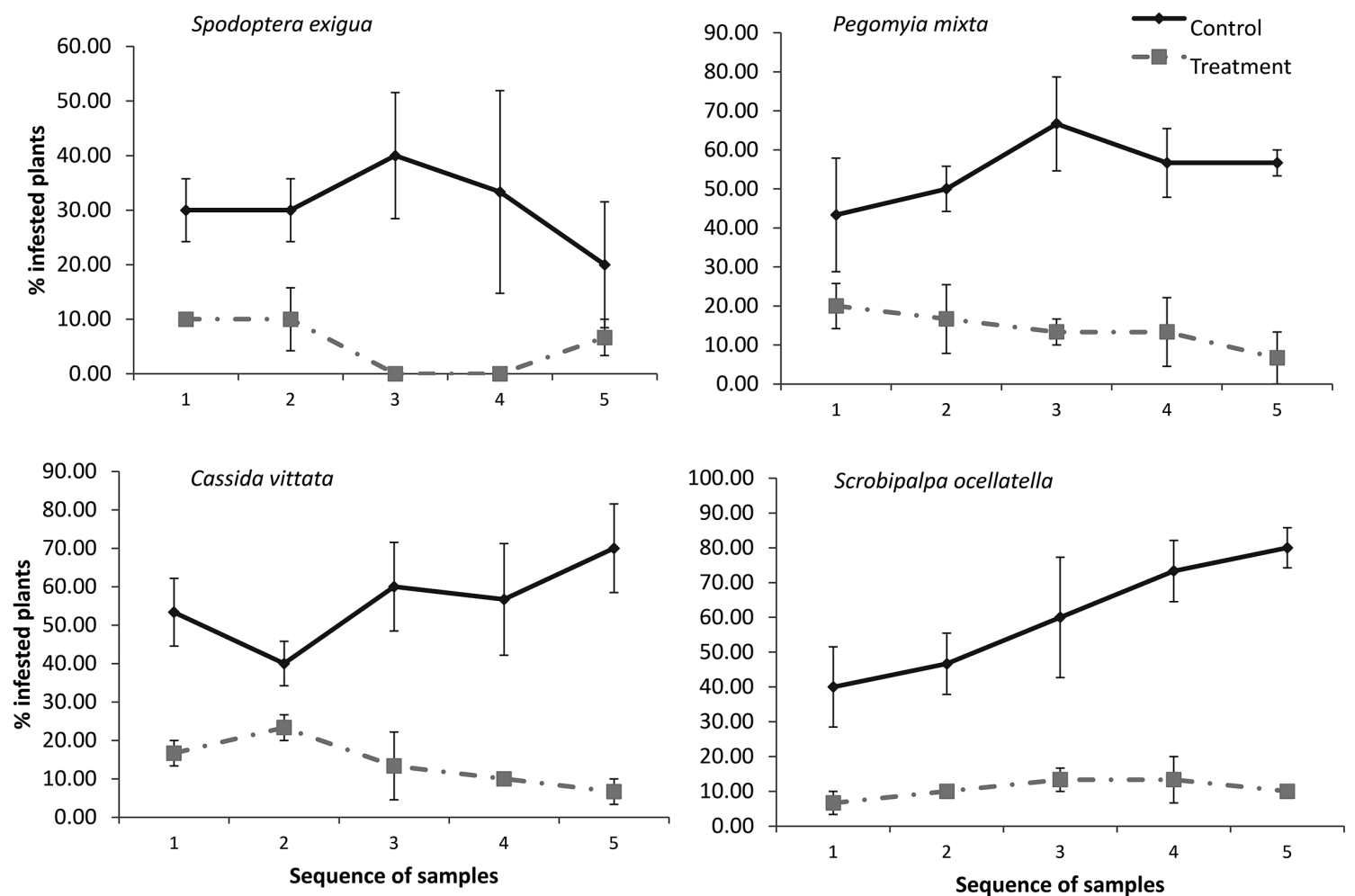

Fig. 2. Mean percentage of infested sugar beet plants treated with Nutrimix ${ }^{\circledR}$ complete or with water (control) in the second season 2016-2017. Sampling was made weekly from 5 days after the fertilizer treatment (from end of October till mid-November)

affected the infestation by $S$. exigua while it had a small, if any, impact on $C$. vittata $(F=3.53 ; P=0.039)$. However, in the second season, in the first sampling date, i.e., five days after application, C. vittata and $S$. exigua were the most influenced among the four pests ( $F=15.12 ; P=0.017$ and $F=12 ; P=0.025$, respectively) (Fig. 2). The percentages of infested plants with the tortoise beetle dropped to $16.67 \pm 3.33 \%$ in treated plants whereas it was $53.33 \pm 8.82 \%$ in control; the infestation by beet armyworm was reduced from $30.00 \pm$ $5.77 \%$ in untreated plants to $10.00 \pm 0.00 \%$ in treated plants (Fig. 2).

The application with nutrients helps plants to produce more succulent and fresh leaves, reduce the deficiency symptoms and increase the yield of crops (Çelik et al., 2010), which means that plant quality can change for herbivorous insects after fertilization. It is well documented that the quality of host plants plays an indispensable role in mediating the population dynamics, reproductive performance, growth, and foraging behavior of herbivorous insects (Awmack and Leather, 2002; Lu et al., 2007; Shah, 2017). Some farming practices, e.g., using mineral nutrients, could ensure that plants have appropriate growing conditions though insect damage may not be affected (Baidoo and Mochiah, 2011). In other case, it was recognized that plants receiving high level of nitrogen attracted more insect pests (Ma and Lee, 1996; Lu et al., 2007; Kulagold et al., 2011). Also, applications of micronutrients such as calcium, zinc and sulphur may negatively affect the pest populations
(Rouhani and Samih, 2013). In the current study, we used Nutrimix ${ }^{\circledR}$ complete which is a mixture of several micronutrients, e.g., zinc, iron, sulfur, manganese, and showed that foliar spray of this fertilizer could help reduce at least some of major pest species in sugar beet fields. We do not know the mechanism and process of how such a foliar application of micronutrients can lead to a reduction of pest populations. Further detailed studies are thus necessary to examine this mechanism and process. In any case, the foliar spray can be a good option for integrated pest management in sugar beet.

In the present study, we further examined the consequence of micronutrient applications on crop yields. The results evidently showed that the yield of taproots was influenced by the application. In the first season of 2015-2016, the mean taproot weight was 72.10 \pm $1.66 \mathrm{ton} / \mathrm{ha}$ in treated plots while it was only $50.40 \pm$ 0.98 ton/ha in untreated plots. The difference was highly significant (Fig. 3; $P=0.0004$ ). In addition, even greater difference was found in the second season of 2016-2017, and the taproot weight in treated plants was $76.80 \pm$ 1.16 ton/ha while it was $43.20 \pm 1.13$ ton/ha in untreated plants (Fig. 3; $P<0.0001$ ). These results evidently demonstrated a great increase in crop yields with micronutrient applications.

The sugar concentration did not differ between control and treated sugar beet plants, both in the first season $(F=0.571 ; P=0.491)$ and in the second one $(F=$ $0.825 ; P=0.415$ ) (Fig. 4). In accordance with our results, Yarnia et al. (2008) reported that an application 


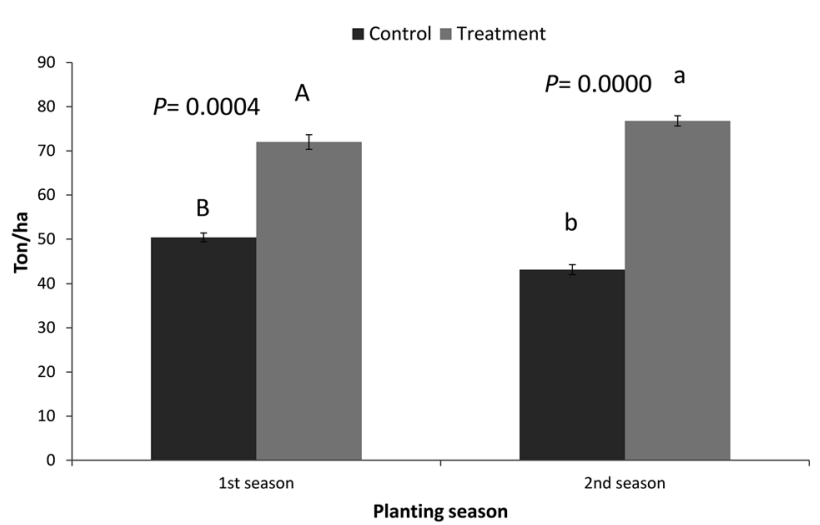

Fig. 3. Mean taproot yields of sugar beet treated with Nutrimix ${ }^{\circledR}$ complete or with water (control) in two successive seasons 2015-2016 and 2016-2017. Vertical lines indicate standard errors. Different letters above bars show a significant difference by the Tukey's HSD test $(P<0.05)$.

of micronutrients to sugar beet plants resulted in high root yields; however, their study also showed the application caused low sucrose contents, which suggested that sugar beet plant quality was rather reduced. Mousavi et al. (2013) indicated that micronutrients such as $\mathrm{Zn}, \mathrm{Mn}$ and Fe were essential trace elements that could enhance sugar beet growth and yield. However, such micronutrients themselves may not increase sugar production per plant individual, leading to a relative reduction of sugar concentration. In contrast, we used a different micronutrient product, which contains nitrogen, etc., other than $\mathrm{Zn}, \mathrm{Mn}$ and Fe, and the difference may be the reason why sugar beet quality was not reduced in the present study though more detailed studies are needed to examine which combinations of micronutrients can be effective to balance sugar beet yield and quality.

\section{Green lacewing releasing}

Species in the genus Chrysoperla have long been considered as important naturally occurring predators in many vegetation systems, and $C$. carnea has been used for controlling a variety of vegetable pests (Brooks, 1994; Wang and Nordlund, 1994; Tauber et al., 2000). However, the control efficiency can depend on type of crops, and little information is available about its capability to control insect pests in sugar beet fields. In the present study, we evaluated the role of $C$. carnea larvae in suppressing sugar beet insect pest populations.

Our results showed that, before the releasing of the predator C. carnea, each sugar beet plant had a mean of $4.00,10.75,8.25,6.50$ and 17.75 individuals of aphid, tortoise beetle, sugar beet moth, leafhopper and sugar beet fly pests, respectively, but after three days of release, the mean numbers of such pests were reduced to 2.25, 9.25, $5.25,4.25$ and 16.00 individuals/plant, respectively. However, such reduction patterns may simply emerge if the pest density decreases as the plant growing stage or

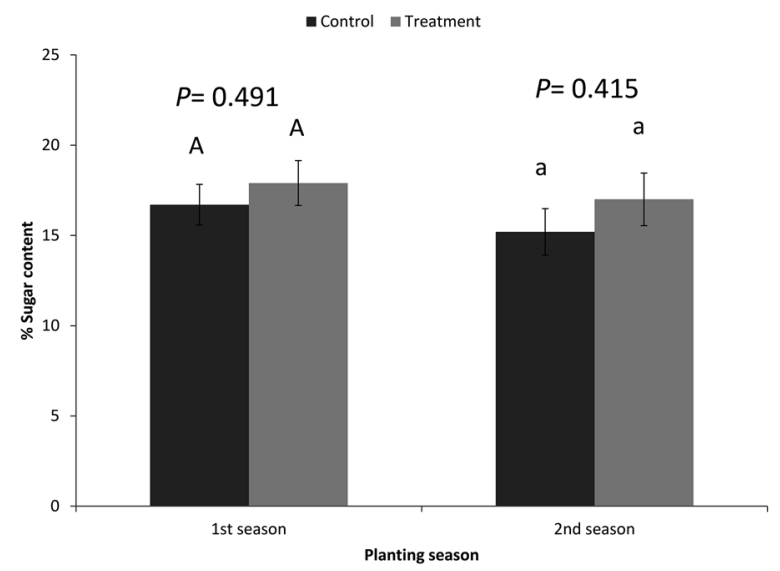

Fig. 4. Mean percentages of sugar content in taproots treated with Nutrimix ${ }^{\circledR}$ complete or with water (control) in two successive seasons 2015-2016 and 2016-2017. Vertical lines indicate standard errors. Significant differences are not detected between the groups with the Tukey's HSD test $(P$ $>0.05)$.

the season goes. In our study, therefore, we calculated reduction percentages of pests on the basis of the comparison with control plants in each sampling date (see the Materials and Methods). The analyses demonstrated that the pest densities decreased significantly on sugar beet plants on which green lacewing larvae had been released (Table 2). It was noticeable that, in the first season of 2015-2016, the population of aphids $(F=$ 7.569; $P=0.0042)$, sugar beet moths $(F=15.121 ; P=$ $0.0002)$, leafhoppers $(F=7.988 ; P=0.0034)$ and sugar beet flies $(F=3.706 ; P=0.0426)$ decreased significantly with the time passage, while the tortoise beetle did not (Table 2). However, in the second season of 2016-2017, only aphid populations were reduced with the passage of time $(F=8.794 ; P=0.002)$, and the other pests were not. On the other hand, the reduction percentages did not significantly differ among insect pests within the same sampling date, i.e. $3^{\text {rd }}, 7^{\text {th }}$ and $10^{\text {th }}$. However, on the last sampling date, i.e. $14^{\text {th }}$ day, aphid populations reached the maximum reduction of $100.00 \pm 0.00 \%$ and $97.08 \pm 2.92 \%$ in the first and second seasons, respectively, while the reduction percentages of sugar beet flies were significantly less (Table 2).

The present results suggest that $C$. carnea larvae were an effective predator to reduce major pest populations in sugar beet fields. Lacewing predators are shown to be most effective when the larvae are released to control the target pests (Tauber et al., 2000). Our study is hence in accordance with previous studies. From the present results, it seemed that the lacewing larvae needed a period of time after being released so as to show significant influences on pest populations. Solangi et al. (2013) reported that young instar larvae of $C$. carnea was much less voracious against the target pest species than the final 3rd instars. In the present study, we released mixed staged larvae of lacewing predators, in which young instars, $1^{\text {st }}$ and $2^{\text {nd }}$ instars, have been included. We suspect that this can be an explanation for 
Table 2. Reduction percentages (\%) of selected sugar beet insect pests after releasing of C. carnea

\begin{tabular}{|c|c|c|c|c|c|c|c|c|c|c|}
\hline \multirow{3}{*}{$\begin{array}{l}\text { Insect } \\
\text { pests }\end{array}$} & \multicolumn{10}{|c|}{ Days after releasing } \\
\hline & \multicolumn{5}{|c|}{ 2015-16 season } & \multicolumn{5}{|c|}{ 2016-17 season } \\
\hline & 3 days & 7 days & 10 days & 14 days & P-value & 3 days & 7 days & 10 days & 14 days & $\mathrm{P}$-value \\
\hline Aphids & $\begin{array}{c}48.45 \pm \\
11.88 \mathrm{Ab}\end{array}$ & $\begin{array}{c}82.83 \pm \\
11.80 \mathrm{Aab}\end{array}$ & $\begin{array}{l}95.72 \pm \\
2.87 \mathrm{Aa}\end{array}$ & $\begin{array}{c}100.00 \pm \\
0.00 \mathrm{Aa}\end{array}$ & 0.0042 & $\begin{array}{l}64.09 \pm \\
5.33 \mathrm{Ac}\end{array}$ & $\begin{array}{l}74.72 \pm \\
6.17 \mathrm{Abc}\end{array}$ & $\begin{array}{c}90.85 \pm \\
5.29 \mathrm{Aab}\end{array}$ & $\begin{array}{l}97.08 \pm \\
2.92 \mathrm{Aa}\end{array}$ & 0.002 \\
\hline $\begin{array}{l}\text { Tortoise } \\
\text { Beetle }\end{array}$ & $\begin{array}{c}21.81 \pm \\
19.24 \mathrm{Aa}\end{array}$ & $\begin{array}{c}54.85 \pm \\
14.21 \mathrm{Aa}\end{array}$ & $\begin{array}{c}58.77 \pm \\
23.72 \mathrm{Aa}\end{array}$ & $\begin{array}{c}89.70 \pm \\
5.95 \mathrm{ABa}\end{array}$ & 0.097 & $\begin{array}{c}16.24 \pm \\
27.82 \mathrm{Aa}\end{array}$ & $\begin{array}{c}32.54 \pm \\
17.68 \mathrm{Aa}\end{array}$ & $\begin{array}{c}61.95 \pm \\
23.33 \mathrm{Aa}\end{array}$ & $\begin{array}{c}75.56 \pm \\
9.88 \mathrm{ABa}\end{array}$ & 0.221 \\
\hline Beet moth & $\begin{array}{l}55.99 \pm \\
2.62 \mathrm{Ab}\end{array}$ & $\begin{array}{l}80.30 \pm \\
3.51 \mathrm{Aa}\end{array}$ & $\begin{array}{l}84.28 \pm \\
3.19 \mathrm{Aa}\end{array}$ & $\begin{array}{c}83.82 \pm \\
4.36 \mathrm{ABa}\end{array}$ & 0.0002 & $\begin{array}{c}37.97 \pm \\
14.16 \mathrm{Aa}\end{array}$ & $\begin{array}{c}63.47 \pm \\
15.97 \mathrm{Aa}\end{array}$ & $\begin{array}{c}70.38 \pm \\
13.40 \mathrm{Aa}\end{array}$ & $\begin{array}{c}80.97 \pm \\
7.12 \mathrm{ABa}\end{array}$ & 0.175 \\
\hline Leafhoppers & $\begin{array}{c}33.07 \pm \\
12.77 \mathrm{Ab}\end{array}$ & $\begin{array}{c}65.53 \pm \\
13.58 \mathrm{Aab}\end{array}$ & $\begin{array}{l}87.71 \pm \\
2.72 \mathrm{Aa}\end{array}$ & $\begin{array}{c}91.88 \pm \\
2.86 \mathrm{ABa}\end{array}$ & 0.0034 & $\begin{array}{c}40.13 \pm \\
23.73 \mathrm{Aa}\end{array}$ & $\begin{array}{l}45.78 \pm \\
21.51 \mathrm{Aa}\end{array}$ & $\begin{array}{c}64.23 \pm \\
18.84 \mathrm{Aa}\end{array}$ & $\begin{array}{c}78.16 \pm \\
10.22 \mathrm{ABa}\end{array}$ & 0.5088 \\
\hline Beet fly & $\begin{array}{l}23.73 \pm \\
9.91 \mathrm{Ab}\end{array}$ & $\begin{array}{c}40.55 \pm \\
17.46 \mathrm{Aab}\end{array}$ & $\begin{array}{l}76.91 \pm \\
6.13 \mathrm{Aa}\end{array}$ & $\begin{array}{c}64.84 \pm \\
13.28 \mathrm{Bab}\end{array}$ & 0.0426 & $\begin{array}{c}29.58 \pm \\
13.96 \mathrm{Aa}\end{array}$ & $\begin{array}{c}35.32 \pm \\
16.73 \mathrm{Aa}\end{array}$ & $\begin{array}{c}42.86 \pm \\
16.13 \mathrm{Aa}\end{array}$ & $\begin{array}{c}49.88 \pm \\
13.11 \mathrm{Ba}\end{array}$ & 0.793 \\
\hline$P$-value & 0.262 & 0.170 & 0.235 & 0.028 & & 0.503 & 0.338 & 0.396 & 0.038 & \\
\hline
\end{tabular}

Means \pm SD are shown. Means followed by the same capital letters in a column and lower case letters in a row do not differ significantly by the Tukey's HSD test $(P<0.05)$.

the time lag between the predator release and pest reduction in our study.

\section{AUTHORS' CONTRIBUTIONS}

In the present study, H. M. Khattab conducted the field experiments. A. E. Youssef, A. S. Ibrahim, and K G. Bazazo designed the field study, prepared the first draft of the manuscript and molding the research concept. T. Ueno participated in manuscript preparation, discussed the results, and polished up the research concept and manuscript. K. M. Mousa analyzed the data, wrote the manuscript and participated in discussion.

\section{CONFLICT OF INTEREST}

The authors declare no conflicts of interest.

\section{REFERENCES}

Abo-Aiana, R. A. D. 1991 Studies on pests of sugar beet in Kafr El-Sheikh, Egypt. Ph.D. Thesis, Fac. of Agric. Tanta Univ., Egypt. 171p

Alghamdi, A., S. Al-Otaibi and S. M. Sayed 2018 Field evaluation of indigenous predacious insect, Chrysoperla carnea (Steph.) (Neuroptera: Chrysopidae), fitness in controlling aphids and whiteflies in two vegetable crops. Egypt J. Biol. Pest Cont., 28: 20

Amin, A. H., A. Helmi and S. A. El-Serwy 2008 Ecological studies on sugar beet insects at Kafr El-Sheikh Governorate, Egypt. J. Agric. Res., 86: 2129-2139

Anonymous 2019 Sugar beet production quantity (tons) for Egypt contains data from the year 1961 until 2017. http://www. factfish.com/statistic-country/egypt/sugar+beet,+production+q uantity, accessed in October $29^{\text {th }} 2019$

Awmack, C. S. and S. R. Leather 2002 Host plant quality and fecundity in herbivorous insects. Annu. Rev. Entomol., 47: $817-844$

Badawy, S. A. E. and G. A. Shalaby 2015 Effect of intercropping of sugar beet with onion and garlic on insect infestation, sugar beet yield and economics. J. Plant Production, Mansoura Univ., 6: 903-914

Baidoo, P. K. and M. B. Mochiah 2011 The influence of nutrient application on the pests and natural enemies of pests of okra Abelmoschus esculentus (L.). J. Appl. Biosci., 41: 2765-2771

Bale, J. S., J. C. van Lenteren and F. Bigler 2008 Biological control and sustainable food production. Philos. Trans. R. Soc. Lond. B. Biol. Sci., 363: 761-776

Bassiony, R. A., F. A. Abou-attia, M. A. Samy, A.E. Youssef and T. Ueno 2017 Parasitoid wasps attacking the American serpentine leafminer Liriomyza trifolii in Kafr EL-Shiekh, Egypt. Int. J. Zool. Invest., 3: 15-20

Bassyouny, A. M. 1993 Studies on preferability and injury level of some main insects to certain sugar beet varieties in Egypt. $J$ Appl. Sci., 8: 213-219

Brooks, S. J. 1994 A taxonomic review of the common green lacewing genus Chrysoperla (Neuroptera: Chrysopidae). Bull. Br. Nat. Hist., 63: 137-210

Çelik, H., A. V. Katkat, B. B. Aşık, M. A. Turan 2010 Effect of foliar-applied humic acid to dry weight and mineral nutrient uptake of maize under calcareous soil conditions. Commun. Soil Sci. Plant Ana., 42: 29-38

Daane, K. M., G. Y. Yokota, Y. Zheng and K. S. Hagen 1996 Inundative release of common green lacewings (Neuroptera: Chrysopidae) to suppress Erythroneura variabilis and E. elegantula (Homoptera: Cicadellidae) in vineyards. Environ. Entomol., 25: 1224-1234

Ebadollahi, A. and M. Mahboubi 2011 Insecticidal activity of the essential oil isolated from Azilia eryngioides (Pau) Hedge et Lamond against two beetle pests. Chil. J. Agr. Res., 71: 406411

Elsharkawy, M. M. and K. M. Mousa 2015 Induction of systemic resistance against papaya ring spot virus (PRSV) and its vector Myzus persicae by Penicillium simplicissimum GP17-2 and silica (Sio2) nanopowder. Inter. J. Pest Manage., 61: 353-358

Evaristo, F. N. 1983 Studies on the insect fauna of sugar beet in Portugal. Bol. Soc. Port. Entomol., 2: 77-94

FAO 2009 Sugar Beet Whit Sugar, FAO Investment Centre Division, Rome, Italy

Gu, H., R. O. Edwards, A. T. Hardy and G. P. Fitt 2008 Host plant resistance in grain crops and prospects for invertebrate pest management in Australia: an overview. Aust. J. Exp. Agric., 48: $1543-1548$

Hagley, E. A. C. and N. Miles 1987 Release of Chrysoperla carnea Stephen (Neuroptera: Chrysopidae) for control of Tetranychus urticate koch (Acarina: Aphididae) on peach grown in a protected environment structure. Can. Entomol., 119: $205-206$

Henderson, C. and E. Tilton 1955 Tests with acaricide against the brown wheat mite. J. Econ. Entomol., 48: 157-162 
Khan, I. and J. G. Mores 1999 Field evaluation of Chrysoperla spp. as predators of citrus thrips. Sarhad J. Agric., 15: 607610

Kulagold, S. D., M. Hegde, G. V. Nayak and A. S. Vastrad 2011 Influence of fertilizer on the incidence of insect pests in paddy. Karnataka J. Agri. Sci., 24: 241-243

López, J. D., R. L. Ridgway and R. E. Pinnell 1976 Comparative efficacy of four insect predators of the bollworm and tobacco budworm. Environ. Entomol., 5: 1160-1164

Lu, Z., X. Yu, K. Heong and C. Hu 2007 Effect of nitrogen fertilizer on herbivores and its stimulation to major insect pests in rice. Rice Sci., 14: 56-66

Ma, K.C. and S. C. Lee 1996 Occurrence of major rice insect pests at different transplanting times and fertilizer levels in paddy field. Korean J. Appl. Entomol., 35: 132-136

Maung, T. A. and C. R. Gustafson 2011 The economic feasibility of sugar beet biofuel production in central North Dakota. Biomass Bioener., 35: 3737-3747

Metwally, S. M., R. El-Sufty, N. EL-Dakhakhny and A. Bassiouny 1987 Effect of infestation with certain insect pests on some sugar beet properties. J. Agric. Res., Tanta Univ., 13: 11191128

Mousa, K. M. and T. Ueno 2019 Intercropping potato with citrus trees as ecologically-based insect pest management. J. Fac. Agr., Kyushu Univ., 64: 71-78

Mousa, K. M., I. A. Khodeir, T. N. El-Dakhakhni and A. E. Youssef 2013 Effect of garlic and eucalyptus oils in comparison to organophosphate insecticides against some piercing-sucking faba bean insect pests and natural enemies populations. Egypt. Acad. J. Biolog. Sci., 5: 21-27

Mousavi, S. R., M. Galavi and M. Rezaei 2013 Zinc (Zn) importance for crop production - A Review. Intel. J. Agron. Plant Production, 4: 64-68

Perez-Alvarez, R., B. A. Nault and K. Poveda 2019 Effectiveness of augmentative biological control depends on landscape context. Sci. Rep., 9: 8664

Rakshit, A. 2013 Pest and disease tolerance in rice cv Pusa basmati as related to different locally available organic manures grown in New Alluvail Region of West Bengal, India. Pak. J. Biol. Sci., 16: 593-597

Reddy, P. P. 2017 Fertilizer management. In: Agro-ecological Approaches to Pest Management for Sustainable Agriculture. Springer Nature Singapore Pte. Ltd, pp. 61-76

Rouhani, M., M. A. Samih 2013 Effects of tank-mixing of micro- nutrients and amitraz by foliar application on abundance of Agonoscena pistaciae in pistachio orchards. Turk. J. Agric Forest., 37: 437-442

Scherr, S. J. and J. A. McNeely 2008 Biodiversity conservation and agricultural sustainability: Towards a new paradigm of "ecoagriculture" landscapes. Phil. Trans. R. Soc. B., 363: 477-494

Shah, T. H. 2017 Plant nutrients and insects development. Int J. Entomol. Res., 2: 54-57

Solangi, A. W., A. G. Lanjar, N. Baloch, M. U. L. Rais and S. A. Khuhro 2013 Population, host preference and feeding potential of Chrysoperla carnea (Stephens) on different insect hosts in cotton and mustard crops. Sindh Univ. Res. J. Sci. Ser., 45 : $213-218$

Tauber, M. J., Tauber, C. A., K. M. Daane and K. S. Hagen 2000 Commercialization of predators: Recent lessons from green lacewings (Neuroptera: Chrysopidae: Chrysoperla). Am. Entomol., 46: 26-38

Turquet, M., J. J. Pommier, M. Piron, E. Lascaux and G. Lorin 2009 Biological control of aphids with Chrysoperla camea on strawberry. Acta Hortic., 842: 641-644

Ueno, T. 2006 Current status of insect pests attacking green bunching onion in central and southern Vietnam. J. Fac. Agric. Kyushu Univ., 51: 275-283

Ueno, T. and D. H. Tran 2015 Neochrysocharis okazakii (Hymenoptera: Eulophidae) as a major parasitoid wasp of stone leek leafminer Liriomyza chinensis (Diptera: Agromyzidae) in Central Vietnam. Psyche, Article ID 179560

Villenave, J., D. Thierry, A. A. Mamun, T. Lodé and E. Rat-Morris 2005 The pollens consumed by common green lacewings Chrysoperla spp. (Neuroptera: Chrysopidae) in cabbage crop environment in western France. Eur. J. Entomol., 102: 547552

Wang, C. L., P. C. Lee and Y. J. Wu 2001 Field augmentation of Orius strigicollis for the control of thrips in Taiwan. In: International Seminar on Biological Control of Insect Pests in Economic Crops. FFTC Extension Bulletin 500: 141-152

Wang, R. and D. A. Nordlund 1994 Use of Chrysoperla spp. (Neuroptera: Chrysopidae) in augmentative release programmes for control of arthropod pests. Biocontrol News Inf., 15: $51-57$

Yarnia, M., M. B. K. Benam, H. K. Arbat, E. F. M. Tabrizi and D. Hssanpanah 2008 Effects of complete micronutrients and their application method on root yield and sugar content of sugar beet cv. Rassoul. J. Food, Agric. Environ., 6: 341-345 
